\title{
Deconstructing Ideas of Violence and Homophobia in Jamaica Sharifa Patel
}

Sharifa Patel is currently a graduate student at McMaster University, pursuing her Masters in Gender Studies and Feminist Research. She completed her Bachelors degree at the University of Toronto with a major in Caribbean Studies and a minor in English and History.

Homophobia in Jamaica is a topic of international debate. From internationally known dancehall artists who sing about murdering or threatening physical violence onto homosexuals, to the media images of the political violence that is played out on vulnerable bodies, the representation of Jamaica as a violent, homophobic space is continually reproduced and perpetuated both domestically and on a global level. Undoubtedly, violence and homophobia share a malevolent relationship in Jamaica and this paper does not seek to deny that reality. Instead this paper will interrogate this popular narrative and investigate Jamaica's violent, homophobic history and how it has been reproduced. The organization of this paper is twofold: I will examine the historical roots of this issue in Jamaica, the proliferation and portrayal of this homophobic narrative on an international scale while also investigating how this violence is played out on the bodies of supposed sexual deviants. Jamaica is not a uniformly homophobic or violent place nor are these attributes innately part of Jamaican culture. These issues stem from a much deeper history of social, political and economic factors that the Jamaican citizenry must grapple with. Jamaicans continue to be denied the ability to create meaningful conversations with their government, and in order to cope with this issue of powerlessness the populations must turn to different means, including violence, to reclaim their political autonomy.

Ideas of acceptable sexual practices cannot be divorced from the legacy of colonialism. Moreover, ideas regarding sexuality and its norms differ between time and place and thus, what is permissible in one space may not be so in another. For instance, since Jamaican history saw the mass migration (predominantly forced migration) of peoples from Africa, India, China, the Middle 
East and Europe, sexual practices of their place of origin were complicated in a country with such a diverse population. The colonial administration, however, regulated sexuality through different arms of the state apparatus including law and the religious doctrine. The colonial ban on sodomy was not limited to same-sex intercourse but rather all non-procreative sexual activity was deemed evil and sinful. ${ }^{1}$ The nineteenth century colonial law, the Offenses Against the Person Act, stated under Unnatural Offenses and the section Outrages on Decency condemned anyone who engaged in buggery or committed "acts of gross indecency with another male" to imprisonment and hard labour. ${ }^{2}$ This law remains intact today prohibiting sexual relationships between same-sex individuals and there is no indication of its amendment. 3 Colonial law serves as a strong influence for current homophobic sentiments in Jamaica and has remained embedded in these existing laws. To reduce homophobia and violence in Jamaica to simply a part of Jamaican culture disregards how foreign influences and laws have shaped the current circumstances of sexual deviants in Jamaica.

The colonial government did not only use law to repress sexual deviants but also used religious infrastructure in order to manipulate enslaved peoples. The enslaved populations were often forced to accept Christian doctrine and forfeit their belief systems for Christ. 4 If enslaved peoples were caught practicing a religion other than Christianity these bodies could be subjected to torture until they at least appeared to comply 5 with the Church. While religions in the Caribbean remain syncretic and often serve as an instrument of resistance, in arguments against sexual deviance, the bible is

\footnotetext{
${ }^{1}$ Suzanne LaFont. "Very Straight Sex: The Development of Sexual Morés in Jamaica" Journal of Colonialism and Colonial History 2:3 2003

2Offences Against the Person Act. Jamaica.

http://www.vertic.org/media/National\%20Legislation/Jamaica/JM_Offences_ag ainst_the_Person_Act.pdf

${ }^{3}$ Current Prime Minister Portia Simpson Miller suggested during her campaign that the Buggery Laws should be revised and that she would allow homosexuals to serve in her cabinet. Since then the laws have remained further discussion on the topic has been limited.

4 Isaac Julien, The Darker Side of Black. 1993.

${ }_{5}^{5}$ Many enslaved peoples participated in Christian religious practices while simultaneously practicing religions from their place of origin or developing religious hybridities that appropriated different aspects of different religions.
} 
constantly quoted. ${ }^{6}$ Sodom has become a key point of reference for those who wish to find a religious basis for assaults on sexually deviant communities.7 The word "sodomite" has become synonymous with homosexuality and we see that this word has continually been used to show contempt, scorn, and hatred throughout dancehall music. ${ }^{8}$ What is particularly interesting about dancehall music is the way in which it has glorified conservative sexuality (or heterosexuality), as it encourages sexual practices that defy modest conventions. Dancehall music graphically describes the act of sexual intercourse often including descriptions of the body and genitalia. This musical form then has completely rejected colonial regulations of sexuality as it pertains to heterosexual sexual relationships while simultaneously appropriating the colonial legacy of homophobia and violence.

Violence in Jamaica cannot merely be dismissed as innately part of Jamaican culture. This type of analysis contributes to a racist continuum that places Jamaica in the 'uncivilized' Global South where violence can be written into the narrative of the country without reflection on how this violence has come into being and how it is reproduced. The western world has made the whole country of Jamaica into a crime scene; our television screens were plastered with images of Tivoli Gardens going up in flames when the United States extradited Christopher 'Dudus' Coke. 9 Tivoli Gardens became Jamaica. It became a country ravaged by crime and violence; the international community saw populations that rallied in the streets to support a criminal. It is these types of images that repeat in western media without any recognition of how the bodies seen on our television screens are fodder for political warfare. ${ }^{10}$

The western media has given no airtime to the real situation in Jamaica. Garrison communities such as Tivoli Gardens are poverty ridden and they have been stripped of the ability to actively, and peacefully, participate in political processes. ${ }^{11}$ The governments,

\footnotetext{
6 Julien

7 Julien

8 See Beenie Man “That's Right" and Mr. Vegas "No Sodomite"

9 CNN May 24, 2010

10 Tivoli Gardens was a JLP enclave and Christopher 'Dudus' Coke had close ties with former Prime Minister Bruce Golding. Lewis

11 Obika, Gray. "Rogue Culture or Avatar of Liberation: The Jamaican

Lumpenproletriat." Social and Economic Studies, Vol. 52, No. 1 (March 2003)
} 
in conjunction with dons in garrison enclaves, have turned these spaces into warzones and have broken their ability to create cohesive communities. ${ }^{12}$ Jamaican dons are well connected to the government and they are able to coerce and threaten their communities into going to war for their territories. Donald "Zeeks" Phipps, a don in Matthew's Lane, is a good case in point. He had extensive political connections, including a half brother who is a parliamentarian representative in central Kingston. ${ }^{13}$ When he was arrested in 1997, his supporters shut down the city for two days. ${ }^{14}$ Our television screens do not include the history of these populations and how they have come to these circumstances. They do not include how the government has pushed its populations into these violent circumstances and used dons in these communities to carry out their control. Instead the western media homogenizes Jamaica as a uniformly violent space placing these violent images in countries that do not face the same realities. By using this medium Jamaica becomes the other of the west, a space that is poor, violent, and homophobic.

Violence in Jamaica is real. There is no doubt that it has one of the highest murder rates per capita in the world. ${ }^{15}$ Indeed this violence is played out on the bodies of the most vulnerable in Jamaica making women, children and sexual deviants in working class communities most susceptible. The international community is very aware of Jamaica's high homicide rates but the issue requires further interrogation as to how this situation emerged and why it continues to plague Jamaica's youth. The revolving international dialogue insists that violence is a characteristic distinct to Jamaican society. This notion must be deconstructed and a more critical analysis of Jamaica's current circumstances in conjunction with its colonial history must be called into question. It is true that we cannot reduce Jamaica's current situation to solely a product of its history but we must examine how it cannot be detached from that history. Colonial rule in Jamaica ushered in spectacular violence and enslaved bodies became the site for sadistic brutality. The

\footnotetext{
12 Lewis

13 "The Americas: Bubba, Bobo, Zambo and Zeeks; Crime in the Caribbean;" The Economist 373, no. 8400 (Nov 06, 2004): 60-42.

http://search.proquest.com/docview/224018010?accountid=14771.

14 ibid

${ }^{15}$ Eric Goldschein. "The 20 Mosts Homicidal Countries In the World." Business Insider. Dec. 12011
} 
mutilations of enslaved bodies were public displays for all to see ${ }^{16}$ and by making a spectacle of these bodies in public spaces we can see how violence can then be exercised to demand compliance. Public violence produces a society that constantly remembers the threat of violence and uses the display of mutilated bodies to regulate society. Even subsequent to the abolition of slavery many draconian colonial laws remained intact and in the 1960s there was even intensification on corporal punishment: in 1963 serious crimes became punishable by flogging and hard labour ${ }^{17}$ and the 1965 Regulation Law elaborated on colonial laws as it permitted the use of the "cat-o-ninetails" and the tamarind switch in prisons. Colonial administration and the inheritors of the Jamaican government followed colonialism's institutionalized violence. Jamaica's current situation then is based on a trajectory of violence.

This history of violence has never been reconciled. Bodies continue to be mutilated in public spaces and the threat of violence still looms heavy on Jamaica's citizenry. As in the colonial era, violence continues to be a means to regulate bodies. Violence has become a government strategy, exercised by gangs in working class communities, to suppress popular resistance. ${ }^{18}$ It also has to be looked at as a means for citizens to cope with their inability to produce meaningful dialogues with their government. There is a difference between politics and governance: governance refers to the bureaucratic and fiscal systems of the state. ${ }^{19}$ Politics affects state activities, and influences concepts of liberty and the how political life is carried out. ${ }^{20}$ Even though Jamaica has a 'democratically' elected government, democracy is not major feature of Jamaican politics and this must be modified to take into consideration contrary practices. ${ }^{21}$

\footnotetext{
16James Bewer Stewart. Venture Smith: The Business of Slavery and Freedom (Massachusetts: University of Massachusetts Press, 2010) 87

17 Obika Gray. Radicalism and social change in Jamaica 1960-1972 122

18 Obika Gray. Demeaned but Empowered. (Mona: University of the West Indies

Press, 2004) 4

19 Rupert Lewis. "Party Politics in Jamaica and the Extradition of Christopher

"Dudus" Coke." The Global South 6, no. 1 (2012): 38-54. http://muse.jhu.edu/ (accessed November 23, 2012)

20 ibid

21 Gray. Demeaned but Empowered. 4
} 
There is a severe disparity between Jamaica's working class communities and their government because of their inability to influence the decisions their government makes. The 1980s saw the Jamaican government formulate agreements with the World Bank and the International Monetary Fund which ushered in Structural Adjustment Programs (SAPs) in order to reduce national debt. ${ }^{22}$ The most disenfranchised populations suffered most under SAPs as the government cut funding for social services and subsidies. ${ }^{23}$ The Jamaican population, particularly women, had to find new avenues of generating income including migrating without their children in order to send remittances back home. ${ }^{24}$ Much of the blame for the increasing violence in Jamaica was placed on women for leaving their homes without structure ${ }^{25}$ but we must consider how women were forced to search for the financial security that their government denied them. Dons in garrison communities were known for their liaisons with government personnel; if a don could coerce their community to vote for a certain party, that party would allocate funds to that don's community. ${ }^{26}$ Dons became powerful in that they could provide the enclave with some social welfare but it came with violent repercussions. ${ }^{27}$

The Jamaican government neglected the basic needs of Jamaica's youth enforcing idleness on them. This enforced idleness translated into gang rivalry as they defended their neighbourhoods in working-class communities. ${ }^{28}$ Youth were caught in a state of powerlessness, unable to have any control over the decisions being made by their governments. Power over themselves, and other bodies for that matter, could only be appropriated through violence and exerting force over other human beings. With that said vulnerable bodies could then be targeted, including homosexual communities. Their bodies could become the site for power to be regained. The rise of garrison communities and donmanship placed certain members of these partisan populations in positions of great

\footnotetext{
22 Beverley Mullings. "Neoliberalization, social reproduction and the limits to labour in Jamaica” Singapore Journal of Tropical Geography. No. 30 (July 2009): 175

23 Mullings 180

24 ibid

25 ibid

26 Mullings 181

27 ibid

28 Gray 5
} 
power. In some cases they have become even more powerful than the government personnel with whom they were once affiliated. ${ }^{29}$ The gun trade was a lucrative business so it was to their advantage for the dons to be thoroughly embedded in these operations. It was highly gendered work that reinforced hyper-masculinity as guns were not only synonymous with a man's strength but the spaces in which they were traded were male dominated.30 In hyper-masculine spaces, homosexual men can find themselves othered and violence becomes a means to express manhood and power. Lesbian women have not been excluded from such abuses. Jamaican LGBT rights activist and poet Stacey-Ann Chin describes how she was sexually assaulted by several men because of her sexual preferences. ${ }^{31}$ She explains that these men did this in attempt to exercise their masculinity and her body became the seat where this could occur. $3^{2}$ Men in working class communities sought to regain power and vulnerable bodies have become the conduits with which this power could be expressed.

The transnational community has become increasingly aware of the violence in the area and LGBT rights groups have lobbied in Canada, the United States and the United Kingdom to keep dancehall artists who sing homophobic lyrics from entering countries. The Stop Murder Music coalition was able to keep Beenie Man out of Miami and he was also pressured to give a public apology.33 Dancehall artists' ability to reach global audiences projects the image of Jamaica as a homophobic space to the international community. Canada's national post published an article named 'Jamaican 'Murder Music' Doesn't Belong in Canada," 34 implicitly saying that murder music belongs and should stay in Jamaica. The article then states that "Akim Larcher...Originally from St. Lucia... moved here a few years ago to escape the anti-gay violence that he says is too prevalent in Caribbean culture." There is implicit racism not only in this

\footnotetext{
29 ibid

30 ibid

${ }^{31}$ Stacey-Ann Chin. National Equity March. 2009

32 ibid

33 Serwer, Jesse. "The Great Dancehall Freeze-Out of 2010." The Village Voice,2010http://search.proquest.com/docview/613371080?accountid=1477 1.

34 “Jamaican 'Murder Music' Doesn't Belong in Canada." National Post.. CanWest MediaWorks Publications Incept. Sept. 22, 2007
} 
statement but in the article: The Caribbean becomes a space where homophobia can exist because it is simply a part of the culture - a culture separate from that of its close Western neighbour. Articles such as this share the negative connotation that homophobia in Jamaica only becomes a hard-edged problem when it is exported to the Western world. However, if homophobic artists remain in Jamaica and continue to preach for violence against homosexuals then it is seen as a non-issue as it is viewed as a conventional feature of the culture and society. Homosexual bodies in Jamaica can be subject to violence that homosexual bodies in the western world are able to avoid simply because of their geographical location and the support systems that lay therein for LGBT communities.

What we see then is that the Caribbean, and more specifically Jamaica, gets glossed over as a uniformly homophobic and violent space as it is often reiterated that Jamaica is the "most homophobic place is the world." 35 Jamaica has become an archetype of Caribbean homophobia on the international scene and dancehall music where violent and homophobic lyrics has gained popularity, with increasing global recognition. Songs such as "Boom Bye, Bye" by Buju Banton and the more recent hit "Chi Chi Mon" by TOK have echoed in the global community and caused much backlash from LGBT rights groups internationally ${ }^{36}$ because these songs promote the murder of homosexuals. $T$ he focus of homophobia has been placed solely on Jamaica with little recognition that similar homophobic sentiments exist elsewhere in the Caribbean but since dancehall is used as a medium to communicate homophobia to an international audience this has enabled Jamaica to be a focal point of international debate concerning the correlation of violence and homophobia. Dancehall music, however, becomes the only voice of the Jamaican citizenry, disregarding the voices that do not hold the same position.

The dancehall scene is dominated by "rude bwoys" who overtly practice and uphold macho ideals. Dancehall music expresses the violence that is real in working class communities and those who participated in the violence in these communities are also present in

35 "The most Homophobic Place on Earth." Time World. April 12, 2006. Even if one place "The most homophobic place on earth" into Google, the first page of links name Jamaica.

36 Jesse 
the dancehall itself. Now it is debated whether the dancehall is a space controlled by males or females, 37 but what is important for this argument is that it is a space that reproduces homophobic music and that it is surely not a safe space for sexual preferences outside of heterosexual affairs. Even in these spaces, however, deviation from heteronomativity still exists. More recently, men in the dancehall scene are taking on an image that deviates from an accepted heterosexual aesthetic. These men may dye their hair blonde, shape their eyebrows and wear fitted pants..$^{8}$ They take to the dance floor more frequently instead of staying on the peripheries. ${ }^{39}$ These men take on an image that would conventionally be understood as homosexual, however these men are generally accepted,40 and indeed welcomed, in the dancehall. So even in a space that is globally understood as extremely hostile to homosexuals, there is room for sexual deviation and certain ambiguities. The dancehall then has the ability to juxtapose the hyper-masculine 'rude bwoy' with the male dancer who appropriates the physical attributes that conventionally defy heterosexuality. This image of a completely homophobic Jamaica must then be deconstructed because inconsistencies and interruptions do occur in the narrative. Those who create these interruptions specifically should not be forgotten and overwritten by the international community.

The international community glosses over the Caribbean as uniformly and innately violent, producing narratives for Jamaica and drowning out the voices of Jamaicans. In so doing, Jamaica as a whole becomes violent and homophobic without any recognition of those who work to reconcile these issues within the country. Sexually deviant populations do exist in Jamaica and their presence within the country deserves recognition. When Jamaica becomes a space that is understood as inherently violent, the autonomy of this portion of the population is completely stripped away. Institutional organizations such as JFLAG do extensive work to resolve this issue of homophobia in Jamaica and they deserve recognition as both Jamaicans, and citizens who demand sexual autonomy. In Jamaica

\footnotetext{
${ }^{37}$ See Carolyn Cooper "Lady Saw Cuts Loose"

38 Nadia Ellis. "Out and Bad: Toward a Queer Performance Hermeneutic in Jamaican Dancehall." Small Axe 15, no. 2 (2011): 7-23. http://muse.jhu.edu/ (accessed March 5, 2013).

39 ibid

40 I have come across one song that is not supportive of men who take on this aesthetic: "Bun a Tight Pants and a Square-Front Shoe" by Trinity Chris
} 
institutional groups, such as JFLAG, work to mediate between civilians and the state, and often work to correct human rights violations. ${ }^{41}$ There needs to be an acknowledgment of the interruptions in the trajectory created by those who transgress sexual norms and these interruptions return agency to the Jamaican public.

Homophobic violence in Jamaica does deserve international attention but the trajectory of violence and homophobia must be analyzed responsibly. The Jamaican citizenry is active and has not passively accepted the circumstances that their government has produced. Vulnerable bodies have indeed become the sight for political violence, but further research is required to truly deconstruct this problem as it relates to Jamaica's history and Jamaica's place in the global economy. Jamaica is not uniformly homophobic or violent; these issues have a history that needs to be recognized and the international community must consider that to divorce Jamaica from the true issues that plague their political structure is to turn Jamaica into a violent space. This view can have dangerous consequences and can very easily produce a discourse based on racist understandings of Jamaican culture. It is in this way that Jamaica can then be associated with a culture of violence to which its citizenry will continue to be subjected.

41 Lewis 
CARIBBEAN QUILT | 2013

\section{Works Cited}

Chinn, Stacey-Ann. National Equity March. 2009

CNN. May 24, 2010

Ellis, Nadia. "Out and Bad: Toward a Queer Performance Hermeneutic in Jamaican Dancehall." Small Axe 15, no. 2 (2011): 7-23. http://muse.jhu.edu/ (accessed March 5, 2013).

Goldschein, Eric. "The 20 Mosts Homicidal Countries In the World." Business Insider. Dec. 12011

Gray, Obika,. "Rogue Culture or Avatar of Liberation: The Jamaican Lumpenproletriat." Social and Economic Studies, Vol. 52, No. 1 (March 2003)

Hope, Donna P.. "Passa Passa: Interrogating Cultural Hybridities in Jamaican Dancehall." Small Axe no. 21 (2006): 125-139. http://search.proquest.com/docview/195805048?accountid=14771

“The most Homophobic Place on Earth." Time World. April 12, 2006.

Julien,Isaac. The Darker Side of Black. 1993.

"Jamaican 'Murder Music' Doesn't Belong in Canada." National Post.. CanWest MediaWorks Publications Incept. Sept. 22, 2007

Jesse, Serwer. "The Great Dancehall Freeze-Out of 2010." The Village Voice, 2010

http://search.proquest.com/docview/613371080?accountid=14771.

LaFont, Suzanne. "Very Straight Sex: The Development of Sexual Morés in Jamaica" Journal of Colonialism and Colonial History 2:3 2003

Mullings, Beverley. "Neoliberalization, social reproduction and the limits to labour in Jamaica" Singapore Journal of Tropical Geography. No. 30 (July 2009): 175 
Offences Against the Person Act. Jamaica. http://www.vertic.org/media/National\%2OLegislation/Jamaica/JM_Offe nces_against_the_Person_Act.pdf

Stewart, James Bewer. Venture Smith: The Business of Slavery and Freedom. Massachusetts: University of Massachusetts Press, 2010. 